\title{
The Risk of Imbalances in the Financing of Social Protection in the Context of Demographic Ageing
}

\section{Summary}

In the next decades, developed countries will experience dramatic changes in their demographic trends. The retirement of the wide baby-boom generations, the increase in life expectancy and the decline in fertility ratios are likely to modify the size and the age-structure of their populations. The expected population ageing in European countries will burden the pension systems, especially wherever the pay-as-you-go pillar is predominant. Recently, migration has received a widespread attention as a solution to expected population decline and ageing in these countries. The flow of (young) migrants to developed countries is perceived as a means to alleviate the financial burden of pension systems. The aim of this contribution is to clarify the issue of aging on labour and capital markets in a macroeconomic perspective. A special attention is given to the risk of imbalances in the financing of social protection in the context of demographic ageing.

\section{Introduction}

In the next decades, developed countries will experience dramatic changes in their demographic trends. The retirement of the wide baby-boom generations, the increase in life expectancy and the decline in fertility ratios are likely to modify the size and the age-structure of their populations. The expected population ageing in European countries will burden the pension systems, especially wherever the pay-as-you-go pillar is predominant. Recently, migration has received a widespread attention as a solution to expected population decline and ageing in these countries. The flow of (young) migrants to developed countries is perceived as a means to alleviate the financial burden of pension systems. The aim of this contribution is to clarify the issue of aging on labour and capital markets in a macroeconomic perspective. 


\section{Facts and figures}

Over the last century the world population increased from 2 billion to 6 billion people. The post-World War II baby boom in Europe has first increased the needs for a support of the below working age generations. Since the baby-boom generations progressively reach maturity, the problem of supporting young people is being replaced by the issue of supporting the elder ones. Since 1990, the age group of 15-29, which constitutes the main source of new entrants on the labour markets, has been decreasing rapidly. Furthermore, the average age of the labour force, which had remained quite stable at around 40 years over several decades, has started to increase since 1995 at a speed of one year every 7 years. Finally, the $65+$ cohort is expected to grow rapidly in the next five years. As a result, labour capacity will be considerably reduced in the EU over the next decades, particularly after 2015 .
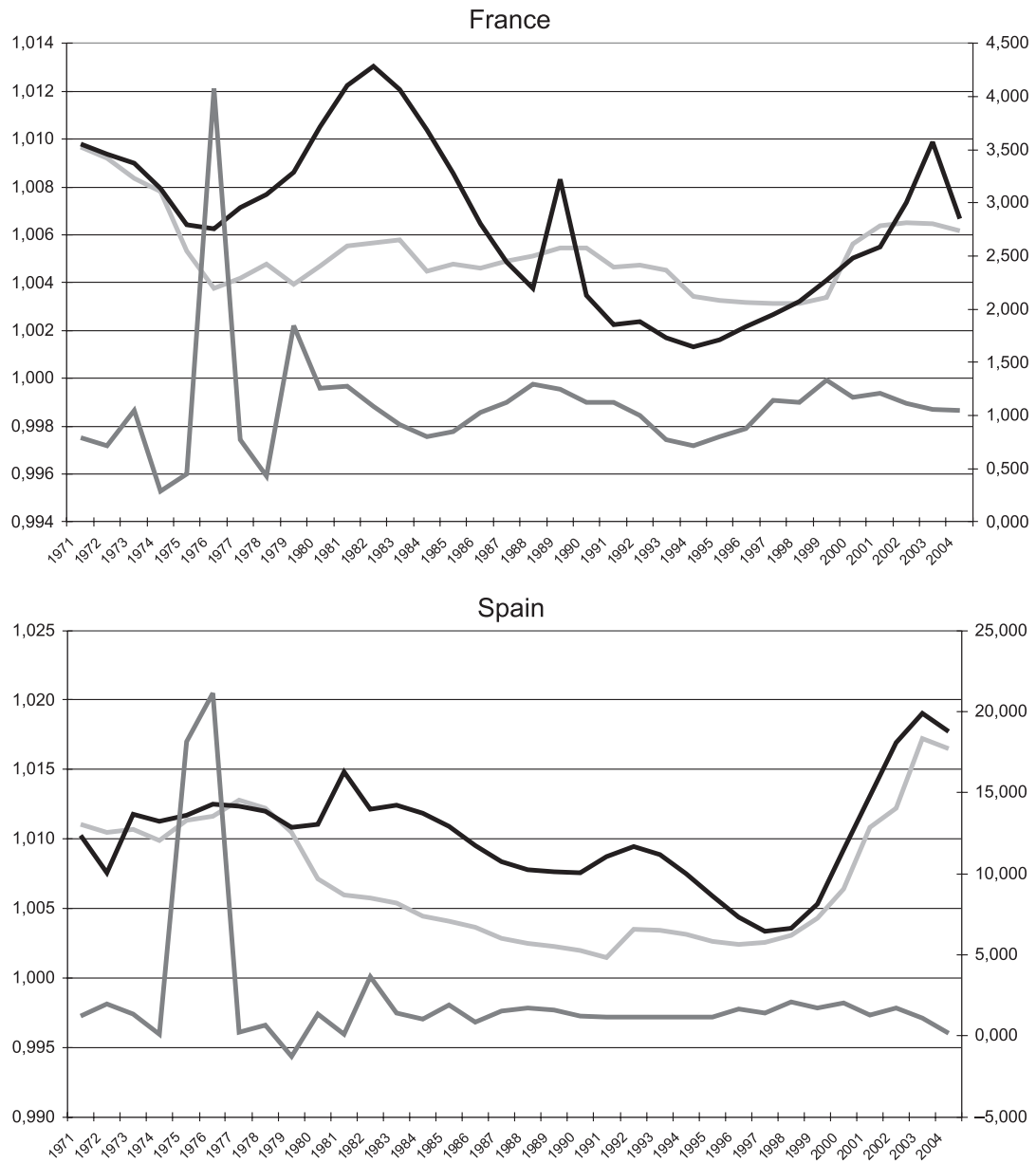


\subsection{Demographic behaviour}

The net migration movements and population growths are characterised by a number of troughs and peaks which generally correspond to well-defined historical events and developments. The German population remains stable during the last 30 years except a peak in 1990 corresponding to the fall of the Iron Curtain. At that time an exodus of population from East to West has been taken place, which gave an increase of German population with $27 \%$. France and Spain have generally the same evolution of the 15-64 age group population (chart 1).
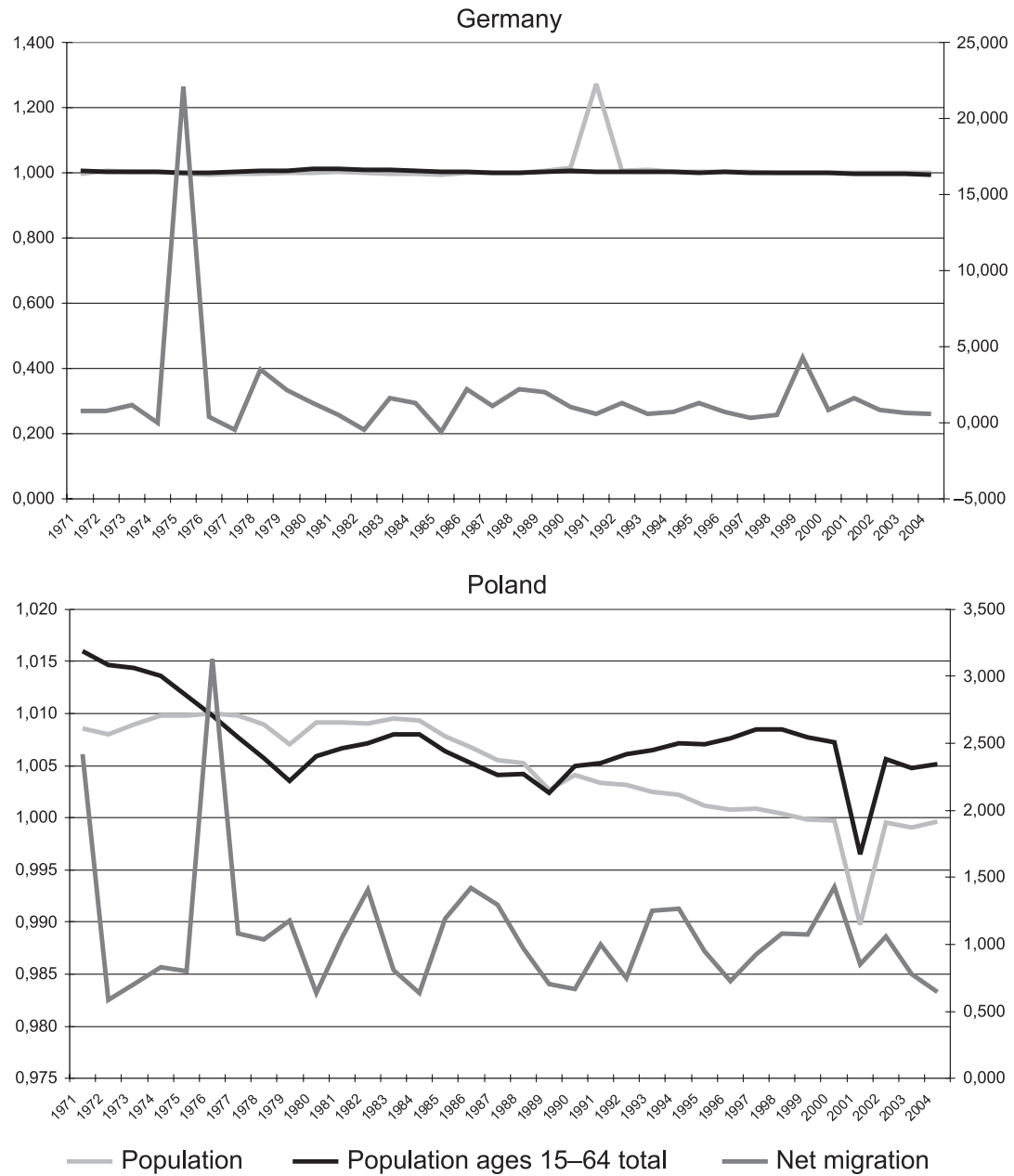

Source: World Bank Data Base and OECD Report "International Migration Outlook 2007".

Chart 1. Population growth and migration movements 
Expected change in the working-age population assuming zero net migration over the periods indicated, 2005-2020 as a percent of the 2005 population

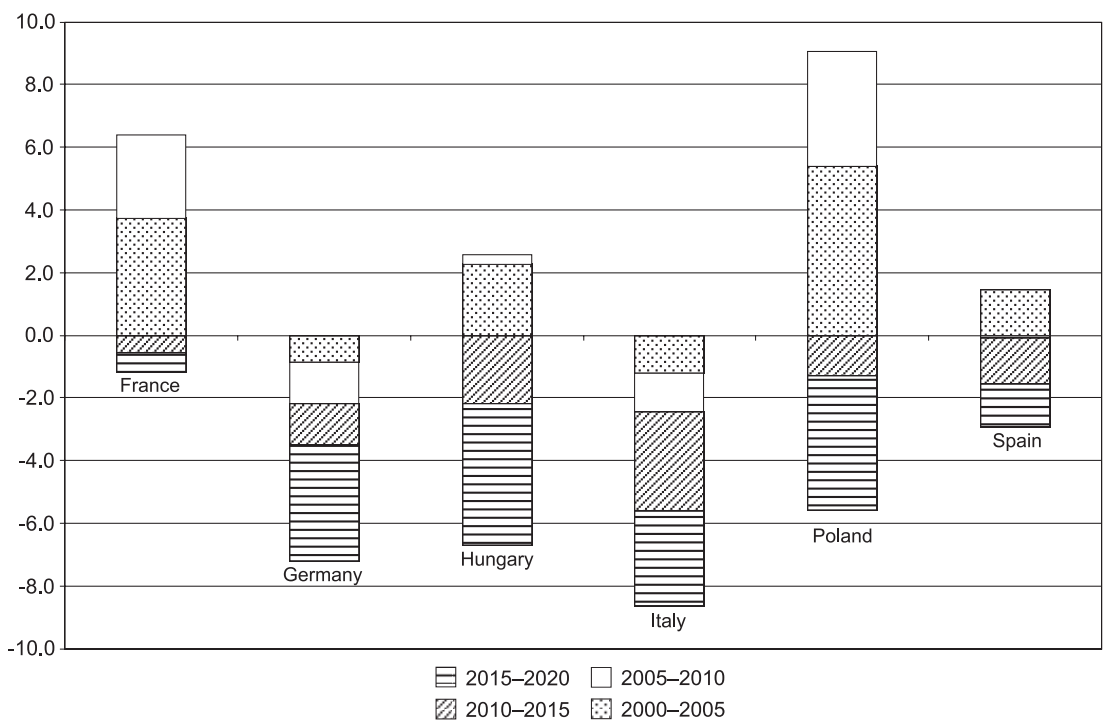

Source: OECD Report "International Migration Outlook 2007".

Chart 2. Changes in working age population ${ }^{1}$

In 2005 the first cohort of post - World War II, baby boom was entering its $60^{\text {th }}$ year. Over the next 20 years the cohorts living the workforce will be larger then those entering in this category because of the fall in birth rates following the baby boom period. This means that without positive net migration the working age population will begin to decline. Italy and Germany are expected to show a decrease in working age population in case of no migration from the period 2000-2005. For Spain the decrease is expected five years later and for France ten years later (chart 2).

In some of the countries the migration has already compensated the decrease in the working age population. More then $40 \%$ of immigrant population in European countries belongs to 25-44 age group (in France 66\% of immigrants are aged 25-44 years old). Taking into account the age structure of immigration (table 8) and in the total population, the loss of growth of the working age popu-

1 The working age population 15-64 for the year 2010 was estimated by taking the population 10-59 observed in 2005 and ageing it 5 years, under the assumption of no death and no migration; the working age population 15-64 for the year 2015 was estimated by taking the population 5-54 observed in 2005 and ageing it 10 years, under the assumption of no death and no migration; the working age population 15-64 for the year 2020 was estimated by taking the population 0-49 observed in 2005 and ageing it 15 years, under the assumption of no death and no migration. 
lation in case of no migration would be in 2006 of $0.2 \%$ annually in Germany, 1.7\% in Spain and 0.3 in France.

The contribution of international migration on population growth compared to natural increase (the excess of births over deaths) is more and more important. For example, Italy has the highest contribution of net migration to population growth in 2004 (chart 3). One exception is France where the contribution of natural increase on population growth is greater than that of net migration.

Alders et al. (2007) within the framework of the project "Uncertain Population of Europe", develop a general methodology for constructing predictive distributions for fertility, mortality and migration combining three approaches: time series analysis, historical forecast errors and expert judgements. Sometimes the results are consistent with the UN results and sometimes they are conflicting. Concerning population growth, they expect a modest annual growth rate of $0.2 \%$ in the 18 Europeans countries studied, reaching the 427 million inhabitants by 2050 . According to the 2004 revision by the UN, the population in the selected countries will decrease between 2030 and 2050 from 407 million to 400 million, after an initial increase from the current level of 392 million (United Nations, 2005). While some recuperation in fertility rate is likely, there is no evidence that it will rise significantly from the current levels. Concerning mortality, most demographic forecasters generally expected a slowdown of the improvement in life expectancy, eventually leading to stagnation. The UPE team expects that it is more likely that current rates of decline will continue, thus leading to a larger future population than predicted by the offi-

Components of population change, 2004, per thousand persons in the population

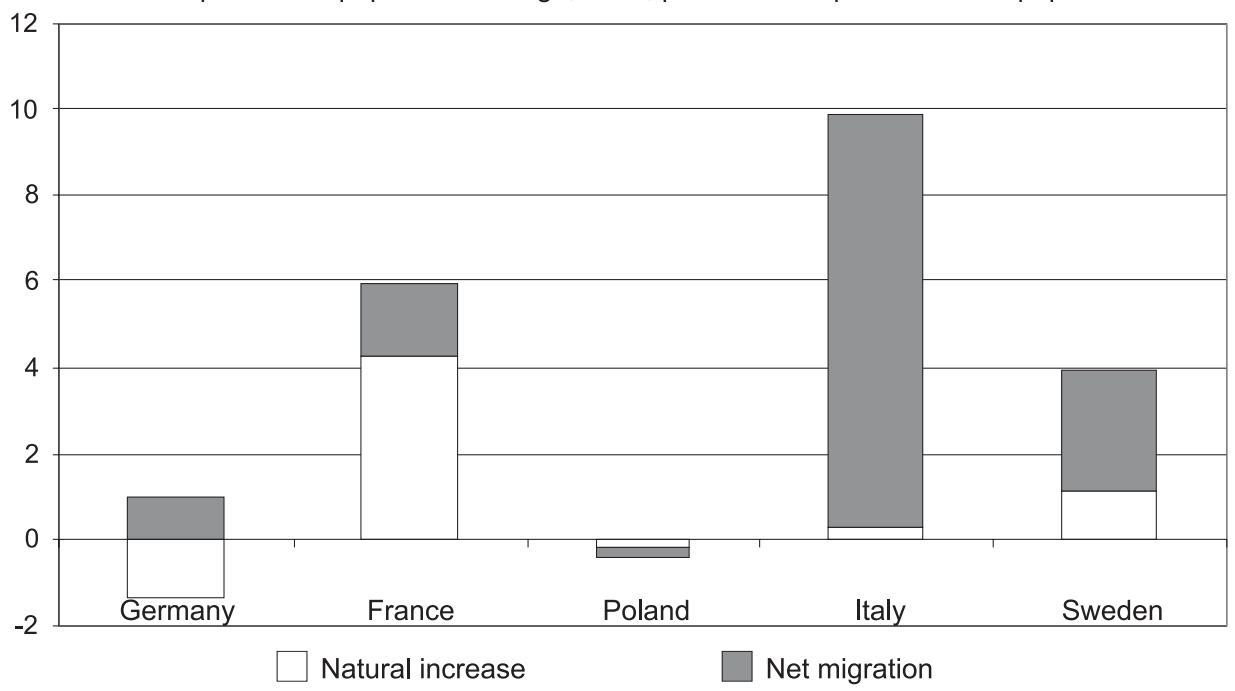

Source: OECD Report "International Migration Outlook 2007".

Chart 3. Components of population change 
cial agencies. Increased immigration and increased life expectancies imply that the number of people aged $65+$ appears rather high in the UPE forecast. For France, Italy and Germany the UPE forecasts of people aged 65+ in 2050 are much higher (18.20 million, 19.29 million and 25.02 million respectively) compared to the estimations of UN (17.11 million, 18.09 million and 22.38 million) (Appendix).

\subsection{Labour markets}

Since 1995 most European countries knew strong growth in employment. The largest increase over the period 1995-2005 was observed in Spain (16,5\%). The net job creation amounted to nearly 7 million in Spain and 2 million in France. A large contribution to this dynamic has been done by immigration. Apart from France, immigrant employment has a stronger growth than the labor market as a whole. The evolution of immigrant employment is principally determined by the inflows of foreign workers over the considered period of time.

Immigrant employment is concentrated in the service sectors as: construction, hotels and restaurants sectors etc. Nowadays, tertiary activities in developed countries account for a preponderant share of employment in general and immigrant employment in particular.

The differences in term of unemployment between the native born population and immigrants have decreased over the last ten years in most of European countries. However, Germany and France have higher unemployment rates for foreign born population then for native population. As for the children of immigrants, the unemployment rate is higher then for the children of natives. For the second generation, the situation becomes better. In the recent immigration countries (Spain and Italy), place of birth makes little difference to unemployment rate.

\subsection{Pension systems}

In the long run, the increasing public expenditure on pensions, social security and health services seems to be the most important issue of the ageing process, because of the speed with which it will develop once the baby boom generation will cross the age of retirement.

According to European Commission Report (2006), “The Impact of Ageing on Public Expenditure: Projections for the EU-25 Member States on Pensions, Health Care, Long-term Care, Education and Unemployment Transfers (2004-2050)", ?for the EU-15 and the Euro area as a whole, public spending is projected to increase by about 4 percentage points between 2004 and 2050, mainly due to increases in public spending on pensions, health care and long-term care. The budgetary impact of ageing becomes visible starting with 2010 . However the largest increases in public spending are projected to take place between 2020 and 2040. 


\section{Sustainability of PAYG pension systems}

\subsection{An overview}

By now, the attention of economists focuses on the direct impact of population ageing on pay-as-you-go pension system. Overlapping generations-models are constructed to analyse intergenerational and intragenerational aspects of the sustainability of social security. In this context, migration is regarded as a possible factor in overcoming the problems of the public pension systems. Regarding the overall fiscal influence of migration on host countries there is a large debate in the economic literature. Immigrants affect a country's fiscal system in many different ways, starting from the moment of arrival and continuing throughout the life cycle (or as long as the immigrant remains in the country).

\subsection{Immigration and pension funds}

Population decline could be prevented by immigration, but population ageing could be prevented only at unprecedented, unsustainable and increasing levels of inflows. This would generate very rapid population growth and rapidly displace the original population from its majority position. Coleman in his study "Replacement Migration', or why everyone's going to have to live in Korea" reviews the options available in response to population ageing, through workforce, productivity, pensions reform and other means. Immigration cannot alleviate population ageing because this one is not caused by a deficit of migration but by a decline in fertility. Changes in pension systems and in the retirement age such that to increase the work force participation in later life could be more appropriate then additional migration. These options could be complemented by a change of the PAYG systems to a funded system. The latter, may imply among other, investing on countries with higher potential in human resources and higher economic growth.

Concerning pension systems, Saczuk (2003) explain in his paper about the replacement migration that, immigrants make little contribution to receiving countries' pension funds. Institutional changes of these systems seem to be both more realistic and more effective.

Wildasin (1994) and Razin \& Sadka (1995) show that in a static environment all income groups may lose from migration. In contrast to the adverse effects of law skilled migration in a static model, Razin and Sadka (1998) prove that in a Samuelsonian overlapping generation model, the migration is a Pareto improving measure. Later, they stated and proved that with a pay-as-you-go pension scheme, an important pillar of welfare state, even the low skilled migration could be beneficial. There are two conditions. The first one is that the economy has good access to international capital markets, so that migration exerts no major effect on factor prices. The second one is the infinite-horizon, the overlap- 
ping generations' economy. Otherwise, even if the migrants are net contributors to the pension system, their contribution does not suffice to support the increase benefit to the old at the time of the migrants' arrival.

\subsection{Accompanying measures in sustaining pension funds}

Leers et al. (2003) show that migration may not be a cure for ageing. The hypothesis that the decrease in fertility implies the increase in wages and thus obtaining an inflow of immigrants that moderates the adverse effects of ageing on public pensions, may not hold if labour is heterogeneous. If the rising dependency ratio induces a strong enough increase in the PAYG-tax, the mobile workers may even decide to leave the ageing country and thus worsen the trouble. In the case of homogeneity, the immigration of workers will take place until the working population is re-established at initial level, preventing the old from a wealth loss. This exceptional case only applies to a small open economy. Otherwise, the inflow of labour will lead to higher wages abroad and ageing will result in less than full replacement of the number of workers before the demographic shock. As a result, wages will increase and pension benefits will decrease.

The work of Blake and Mayhew (2004) suggests that beyond 2020, some accompanying measures such as increasing contribution rates and/or the state pension age will be necessary to manage the pension increases due to population ageing. After 2020 the necessary levels of immigration will increase to unrealistic and unsustainable levels. Although, an increase in UK fertility rates over the next few years would be beneficial since this would help boost the contribution base in the longer term, but it would not solve the problems in the decade beginning in 2020.

\section{Conclusion}

While EU is a relatively wealthy and politically stable world region with an aging population, and neighbouring countries to the South and South-East are much poorer and politically and economically less stable, but have young and growing populations, migration from south to north is almost inevitable. The enlargement of EU may further complicate the issue of sustainability of pension systems, as long as the new member states face similar demographic problems. It is important to recognise the significant implications for employment policies that an enlarged Union will represent. The existing differential in economic terms is expected to generate a considerable inflow of immigrants from these countries. The challenge, therefore, is how to manage - not how to prevent migration to Europe.

In conclusion, finding the appropriate measures to overcome the side effects of the ageing process in developed countries is a quite complicated issue that 
cannot be treated by taking only into account the demographic trends. Each country represent a different situation not only because of the demographic patterns but also because its own socioeconomic reality. Economic and social institutions are often different too.

\section{References}

Alders M., Keilman N., Cruijsen H., Assumptions for Long-term Stochastic Population Forecasts in 18 European Countries, "European Journal of Population", 2007 no 23.

Arnott R.D., Casscells A., Demographics and Capital Market Returns, "Financial Analysts Journal", 2003.

Artus P., Ouverture des échanges avec les émergents, flux de capitaux, flux migratoires, Document de travail n 15 , CDC-IXIS, Paris 2006.

Bermingham J.R., Immigration: Not a Solution to Problems of Population Decline and Aging, "Population and Environment: A Journal of Interdisciplinary Studies", 2001 no 22 (4).

Bijak J., Kupiszewska D., Kupiszewski M., Saczuk K., Kicinger A., Population and Labour Force Projections for 27 European Countries, 2002-2052: Impact of International Migration on Population Ageing, "European Journal of Population", 2007 no 23.

Bouvier L.F., Replacement Migration: Is it a Solution to Declining and Aging Populations?, "Population and Environment: A Journal of Interdisciplinary Studies", 2001 no 22 (4).

Blake D., Mayhew L., Immigration or Bust? Options for Securing the Future Viability of the UK State Pension System, Discussion Paper, Pensions Institute, 2006.

Bosworth B.P., Bryant R.C., Burtless G., The Impact of Aging on Financial Markets and the Economy: a Survey, CRR WP, 2004.

Coleman D.A., Who's Afraid of Low Support Ratios? A UK Response to the United Nations Population Division Report of Replacement Migration, paper presented at the Expert Group Meeting on Policy Responses to Population Ageing and Population Decline, United Nations Population Division, New York 2000, 16-18 October.

Espenshade T.J, Replacement Migration: from the Perspective of Equilibrium Stationary Populations, "Population and Environment: A Journal of Interdisciplinary Studies", 2001 no 22 , (4).

European Commission, The Impact of Ageing on Public Expenditure: Projections for the EU25 Member States on Pensions, Health Care, Long-term Care, Education and Unemployment Transfers (2004-2050), Report 2006.

Federici D., Giannetti M., Temporary Migration and Foreign Direct Investment, CIDEI Working Paper No. 72, 2006.

Fehr H., Jokisch S., Kotlikoff L., The Developed World's Demographic Transition - The Roles of Capital Flows, Immigration, and Policy, NBER Working Paper No. 10096.

Fehr H., Jokisch S., Kotlikoff L., The Role of Immigration in Dealing with the Developed World's Demographic Transition, NBER Working Paper No. 10512, 2004

Fotakis C., Demographic Ageing, Employment Growth and Pensions Sustainability in the EU: The Option of Migration, Expert Group meeting on policy responses to population ageing and population decline, 2000.

Grant L., Replacement Migration: The UN Population Division on European Population Decline, "Population and Environment: A Journal of Interdisciplinary Studies", 2001 no 22 (4).

Group of Ten, Ageing and Pension System Reform: Implications for Financial Markets and Economic Policies, 2005.

Leers T., Meijdam L., Verbon H.A.A., Ageing, Migration and Endogenous Public Pensions, "Journal of Public Economics", 2003, no 88.

McNicoll G., Reflections on Replacement Migration, "People and Place", 2000 no 8 (4). 
Razin A., Sadka E., Migration and Pension, NBER Working Paper No 6778, 1998.

Razin A., Sadka E., Migration and Pension with International Capital Mobility, "Journal of Public Economics", 1999a, no 74.

Razin A., Sadka E., Unskilled Migration: a Burden or a Boon for the Welfare State, NBER Working Paper No 7013, 1999b.

Razin A., Sadka E., Welfare Migration: Is the Net Fiscal Burden a Good Measure of its Economic Impact on the Welfare of the Native Born Population?, NBER Working Paper No 10682, 2004.

Razin A., Sadka E., Swagel P., The Ageing Population and the Size of Welfare State, NBER Working Paper No 8405, 2001.

Saczuk K., A Development and Critique of the Concept of Replacement Migration, CEFMR Working Paper, 2003.

United Nations, Replacement Migration: Is it A Solution to Declining and Ageing Populations?, Population Newsletter, United Nations Population Division, New York 2000.

Wildasin D.E., Income Redistribution and Migration, "Canadian Journal of Economics", 1994 no 27 (3).

Wildasin D.E., Public Finance in an Era of Global Demographic Change: Fertility Busts, Migration Booms, and Public Policy, 2006.

\section{Ryzyko nierównowagi w finansowaniu polityki ubezpieczeń społecznych w kontekście zmian demograficznych}

\section{Streszczenie}

W kolejnych dekadach kraje rozwinięte doświadcza dramatycznych zmian $w$ trendach demograficznych. Zmiana struktury wiekowej emerytów, przechodzenie na niq osób z pokoleń wyżu demograficznego, wydtużenie czasu ich życia i zmniejszenie stopnia dzietności mtodszych pokoleń moga zmodyfikować jej wielkość. Stopniowo następujace starzenie się społeczeństw w krajach europejskich znacznie obciąży systemy emerytalne, szczególnie te najczęściej obowiq̨zujące typu pay-as-you-go. W ostatnim czasie uważa się, że migracje ludzi z krajów stabiej rozwiniętych moga zatrzymać te negatywne trendy w krajach rozwiniętych ekonomicznie. Strumień migracji mtodych osób do krajów rozwiniętych jest postrzegany jako szansa tagodzenia ciężaru finansowego systemów emerytalnych. Celem artykutu jest wyjaśnienie zjawiska zmian na rynku pracy $i$ ubezpieczeń społecznych oraz wynikajacych $z$ tego zmian $w$ polityce makroekonomicznej. Specjalna uwaga skupiona jest na analizie ryzyka braku równowagi w finansowaniu ubezpieczeń społecznych w kontekście zachodzacych zmian demograficznych. 


\section{Appendix - Tables}

Table 1. Total Population (in ' 000)

\begin{tabular}{|c|c|c|c|c|c|c|}
\hline & France & Germany & Italy & UK & EU \\
\hline \multicolumn{2}{|c|}{ Population 2002} & 59486 & 82482 & 57157 & 59232 & 494179 \\
\hline \multirow{6}{*}{$\begin{array}{l}\text { UE } \\
\text { projec- } \\
\text { tions (EU } \\
15)\end{array}$} & Scenario I & 59883 & 73303 & 41197 & 56667 & 331307 \\
\hline & Scenario II & 59357 & 58812 & 40722 & 55594 & 310839 \\
\hline & Scenario III & 61121 & 81661 & 57338 & 58833 & 372440 \\
\hline & Scenario IV & 67130 & 92022 & 66395 & 64354 & 418509 \\
\hline & Scenario V & 81719 & 113181 & 87345 & 74398 & 519965 \\
\hline & Scenario VI & 187193 & 299272 & 193518 & 136138 & 1228341 \\
\hline \multirow{4}{*}{$\begin{array}{l}\text { Bijak et al. } \\
\text { (UE 27) }\end{array}$} & Low Scenario & 64230 & 71096 & 48280 & 52292 & 446928 \\
\hline & Base Scenario & 70381 & 77007 & 54044 & 65481 & 494922 \\
\hline & High Scenario & 79189 & 86093 & 62813 & 74353 & 562967 \\
\hline & No Migration Scenario & 60149 & 63151 & 43678 & 55020 & 414730 \\
\hline
\end{tabular}

Table 2. Potential Support Ratio (in \%)

\begin{tabular}{|l|l|c|c|c|c|c|}
\hline \multicolumn{2}{|l|}{} & France & Germany & Italy & UK & EU \\
\hline PSR 2002 & 4.00 & 3.91 & 3.55 & 4.19 & 4.19 \\
\hline \multicolumn{2}{|l|}{ UE projections (UE 15) } & 2.26 & 1.75 & 1.52 & 2.36 & 1.89 \\
\hline \multirow{3}{*}{$\begin{array}{l}\text { Bijak et al. } \\
\text { (UE 27) }\end{array}$} & Low Scenario & 1.97 & 1.53 & 1.33 & 1.99 & 1.64 \\
\cline { 2 - 7 } & Base Scenario & 2.15 & 1.72 & 1.48 & 2.19 & 1.82 \\
\cline { 2 - 7 } & High Scenario & 2.38 & 1.97 & 1.70 & 2.47 & 2.05 \\
\cline { 2 - 7 } & No Migration Scenario & 1.87 & 1.42 & 1.22 & 1.89 & 1.56 \\
\hline
\end{tabular}

Table 3. Total Fertility Rate (in \%)

\begin{tabular}{|l|c|c|c|c|c|}
\hline & France & Germany & Italy & UK & EU \\
\hline UE projections (2045-2050) (UE 15) & 1.96 & 1.64 & 1.66 & 1.9 & 1.8 \\
\hline Bijak et al. (UE 27) & 1.90 & 1.50 & 1.50 & 1.8 & - \\
\hline Alders et al. & 1.80 & 1.40 & 1.40 & 1.8 & - \\
\hline
\end{tabular}

Table 4. Life Expectancy (years)

\begin{tabular}{|l|l|c|c|c|c|}
\hline \multicolumn{2}{|c|}{} & France & Germany & Italy & UK \\
\hline \multirow{3}{*}{ Bijak et al. } & Male & 84.7 & 84.7 & 85.0 & 84.8 \\
\cline { 2 - 6 } & Female & 89.7 & 88.6 & 89.8 & 87.9 \\
\hline \multirow{2}{*}{ Alders et al. } & Male & 85.5 & 84.9 & 85.7 & 83.4 \\
\cline { 2 - 6 } & Female & 89.7 & 89.1 & 89.8 & 87.5 \\
\hline
\end{tabular}


Table 5. Yearly Net Migration (in '000)

\begin{tabular}{|l|l|r|r|r|r|r|}
\hline \multicolumn{2}{|c|}{} & \multicolumn{1}{|c|}{ France } & Germany & \multicolumn{1}{c|}{ Italy } & \multicolumn{1}{c|}{ UK } & EU \\
\hline \multirow{4}{*}{$\begin{array}{l}\text { UE } \\
\text { projections } \\
(\text { UE 15) }\end{array}$} & Scenario I & 110 & 2519 & 109 & 341 & 724 \\
\cline { 2 - 7 } & Scenario II & 0 & 0 & 0 & 0 & 0 \\
\cline { 2 - 7 } & Scenario III & 500 & 4244 & 4414 & 899 & 2548 \\
\cline { 2 - 7 } & Scenario IV & 1854 & 6009 & 6531 & 2132 & 4262 \\
\cline { 2 - 8 } & Scenario V & 5423 & 9842 & 12248 & 4643 & 8188 \\
\cline { 2 - 8 } & Scenario VI & 30430 & 44825 & 39818 & 20383 & 36194 \\
\hline \multirow{3}{*}{$\begin{array}{l}\text { Bijak } \\
\text { (UE 27) }\end{array}$} & Low Scenario & 44723 & 61903 & 57321 & 44424 & - \\
\cline { 2 - 8 } & Base Scenario & 149075 & 206342 & 171963 & 148080 & - \\
\cline { 2 - 8 } & High Scenario & 289151 & 412683 & 343926 & 296160 & - \\
\hline Alder \& al. & 1.5 & 3.5 & 4.5 & 3.5 & - \\
\hline
\end{tabular}

UE Projections: Average annual net number of migrants between 2000 and 2050, per million inhabitants in 2000, by scenario and country or region

Bijak et al. : Yearly net migration from the Rest of the world for 2052

Alders et al.: Net migration (per 1,000 population in 2000) for 2049

Table 6. Labour market indicators: native born versus foreign born

\begin{tabular}{|c|c|c|c|c|c|}
\hline & & & France & Germany & Spain \\
\hline \multirow{6}{*}{$\begin{array}{l}\text { Participation } \\
\text { rate (\%) }\end{array}$} & \multirow{3}{*}{ Native-born } & 1995 & 68,4 & .. & 59,4 \\
\hline & & 2000 & 69,6 & 72,1 & 64,9 \\
\hline & & 2005 & 69,6 & 74,8 & 68,6 \\
\hline & \multirow{3}{*}{ Foreign-born } & 1995 & 66,7 & .. & 64,2 \\
\hline & & 2000 & 67,4 & 64,8 & 71,4 \\
\hline & & 2005 & 66,6 & 68,7 & 78,7 \\
\hline \multirow{6}{*}{$\begin{array}{l}\text { Unemployment } \\
\text { rate (\%) }\end{array}$} & \multirow{3}{*}{ Native-born } & 1995 & 11,2 & .. & 22,8 \\
\hline & & 2000 & 9,4 & 7,4 & 13,9 \\
\hline & & 2005 & 8,6 & 10,4 & 9,1 \\
\hline & \multirow{3}{*}{ Foreign-born } & 1995 & 17,6 & .. & 27,0 \\
\hline & & 2000 & 16,7 & 12,6 & 15,9 \\
\hline & & 2005 & 14,7 & 17,0 & 11,3 \\
\hline \multirow{6}{*}{$\begin{array}{l}\text { Employment rate } \\
\text { (\%) }\end{array}$} & \multirow{3}{*}{ Native-born } & 1995 & 60,7 & .. & 45,8 \\
\hline & & 2000 & 63,1 & 66,7 & 55,9 \\
\hline & & 2005 & 63,6 & 67,0 & 62,3 \\
\hline & \multirow{3}{*}{ Foreign-born } & 1995 & 55,0 & .. & 46,8 \\
\hline & & 2000 & 56,2 & 56,7 & 60,0 \\
\hline & & 2005 & 56,8 & 57,0 & 69,8 \\
\hline
\end{tabular}

Source: OECD Annual Report 2007, International Migration Outlook. 
Table 7. Skilled Immigration

\begin{tabular}{|c|c|c|c|c|c|c|}
\hline & \multirow{2}{*}{\multicolumn{2}{|c|}{$\begin{array}{c}\text { Immigrants } \\
\text { (\% in total population) }\end{array}$}} & \multicolumn{4}{|c|}{ Skilled immigrants (\% in total number of immigrants) } \\
\hline & & & \multirow{2}{*}{$\begin{array}{c}M \\
1990\end{array}$} & \multirow{2}{*}{\begin{tabular}{|c|}
$M$ \\
2000
\end{tabular}} & \multirow{2}{*}{\begin{tabular}{|c|}
$F$ \\
1990
\end{tabular}} & \multirow{2}{*}{$\begin{array}{c}F \\
2000\end{array}$} \\
\hline & 1995 & 2005 & & & & \\
\hline France & 8.7 & 8.5 & 21.9 & 21.9 & 8.6 & 16.4 \\
\hline Germany & 5.5 & 7.3 & 21.8 & 25.5 & 17.0 & 21.0 \\
\hline Spain & 3.3 & 4.5 & 9.5 & 12.2 & 17.5 & 16.8 \\
\hline UK & 6.8 & 8.3 & 13.9 & 17.8 & 20.5 & 34.5 \\
\hline US & 8.7 & 11.7 & 39.2 & 51.3 & 40.1 & 42.5 \\
\hline EU 15 & 5.5 & 6.7 & 15.5 & 18.6 & 17.1 & 23.1 \\
\hline
\end{tabular}

Source: Docquier, Marouk (2005).

Table 8. Age Structure of Migration (in 2006)

\begin{tabular}{|l|c|c|c|c|}
\hline & $15-24$ & $25-44$ & $45-64$ & $>65$ \\
\hline France & & 66 & 25 & 9 \\
\hline Spain & 16 & 41 & 20 & 23 \\
\hline Germany & 8 & 40 & 27 & 25 \\
\hline
\end{tabular}

Source: IXIS CIB database. 